\title{
Implementation of Transmigration Settlement Unit Transformation to Village Policy for Increasing Society Welfare in Indonesia
}

\author{
Jufri Syahruddin \\ Institut Pemerintahan Dalam Negeri \\ Khasan Effendy \\ Institut Pemerintahan Dalam Negeri \\ Muchlis Hamdi \\ Institut Pemerintahan Dalam Negeri \\ Triyuni Soemartono \\ Universitas Moestopo (Beragama)
}

Received: May 20, 2019 Accepted: July 3, 2019 Online published: July 8, 2019

doi:10.5296/jpag.v9i2.14806 URL: https://doi.org/10.5296/jpag.v9i2.14806

\begin{abstract}
This research relies on the concept of process theory and policy implementation determinants from Hamdi (2014), where the theoretical concepts of policy implementation processes include dimensions of productivity, linearity, and efficiency, while the theoretical determinants of policy implementation include substance policy factors, behavior of implementing tasks, network interactions employment, target group participation, and resource factors. The research method used in this study is a qualitative research method with the characteristics of construction built on natural conditions, more descriptive, more emphasis on processes, inductive analysis, and more emphasis on the value or meaning contained in a data or event. In an effort to obtain accurate analysis results related to the process and the determinants of the implementation of the transmigration settlement unit transformation into Madapuhi Trans Village, the informants selected were all stakeholders at
\end{abstract}


the local level, both local government and the community. This study found that the process of implementing the UPT transformation policy into Madapuhi Trans Village has not gone well, as indicated by low productivity, lack of linearity and lack of efficiency in policy implementation, as well as several factors that hinder successful implementation of policies such as Policy Substance, Implementing Task Behavior, Target Group Participation, and Resources. The supporting factors in implementing this policy are factors of network interaction. The results also showed that from the 5 determinants of policy implementation, the Target Group Participation factor was the most influential factor in the context of the implementation of the transformation of the transmigration settlement unit to the Madapuhi Trans Village. This study found that understanding harmony is also a determinant of policy implementation. The model produced by this research is the model of the Effectiveness of the Process of Implementing the Policy of Transforming the UPT into a village. Based on the results and findings of the study, it is suggested that a theory of the implementation of the transformation of the transmigration settlement unit into a village be developed, which includes the theory of the process of policy implementation and the determinant theory of policy implementation by Hamdi.

Keywords: Policy Implementation, Transmigration Settlement Unit Transformation, Village Establishment, Social Welfare

\section{Introduction}

Decentralization essentially brings the government closer to the community, provides better services to community groups and promotes freedom, equality, and well-being (Smith, 2012), so that decentralization is expected to build the leading public service unit in direct contact with the community, focus development in smaller territories, and facilitate government administration. Based on this concept, the village as the smallest territory has a strategic position and role in realizing the success of an effective and efficient decentralization concept. The formation of villages in transmigration settlements in Indonesia uses a pattern of transfer (transformation) of transmigration settlement units to definitive villages, as stipulated in article 32 of Law Number 29 of 2009 concerning Amendments to Law Number 15 of 1997 concerning Transmigration and strengthened by considering Article 13 of the Law - Law Number 6 of 2014 concerning Villages, even though the process of formation is implicitly not specifically or individually regulated but arranged together with the establishment of genealogical villages. This condition has consequences for general formation requirements, without regard to the specificity of transmigration settlement units as national strategic interests or state interests which should be by design.

The essence of the objectives of village structuring (including the establishment and division of villages) are:

1. To realize the effectiveness of organizing village governance;

2. Accelerating the improvement of the welfare of rural communities;

3. Speeding up the quality of public services; 
4. Improve the quality of village governance; and

5. Increasing village competitiveness.

Based on these objectives, it is clearly implied that the purpose of village formation is to accelerate the improvement of the welfare of the village community, so that efforts to form a village, both by the regional government and through the policies of the central government, must refer to improving the welfare of the village community. Villages formed from transmigration settlement units in North Maluku Province showed success in their development, such as in East Halmahera Regency, where villages formed from transmigration settlement units in the subaim region experienced significant developments, especially concerning economic conditions and governance. Increasing economic conditions can be seen from the existence of village markets and shops, agricultural production and plantations that have implemented patterns of intensification and diversification of plants, the existence of savings and loan cooperatives and the existence of inns and hotels, which of course all shows growing economic activity. In the area of governance, these villages have experienced significant developments such as access to adequate health and safety, good education and transportation facilities, and some villages have experienced an increase in government status to sub-districts, and have even been proposed as New Autonomous Regions.

At the national level, the success of the villages originating from the transformation of the Transmigration Settlement Unit to the Village was presented in the results of Subroto's research such as 1) transmigration villages in Belitang, South Sumatra and villages in Metro Lampung Tengah, whose agricultural production remained maximal and distribution that is smooth and absorbed by the domestic market, 2) transmigration villages in Parigi, Central Sulawesi, which since 2005 have become one of the rice barns in Central Sulawesi, 3) transmigration villages in Batumarta, South Sumatra which have since experienced Repelita III and IV expansion of rubber plantations is quite significant, namely from 1 hectare per head of family to 3-4 hectares per head of family, so that the income of the community in these villages is quite large and able to improve their welfare, 4) transmigration villages in Timika Papua, where farmers' production is absorbed in the domestic market. This condition is indeed possible because of the high demand for agricultural products from PT Freeport, 5) transmigration villages in Batu Betumpang Bangka, where rural communities have a high income by developing food crops and pepper plants, and 6) transmigration villages in the Bahar River Jambi, which was originally a UPT with an oil palm plantation business pattern (PIR-Trans credit: Inpres Number 01/86) then experienced rapid development so that the community was able to repay loans and interest and was even able to attract new investors for the development of their oil palm business (Subroto, 2015).

The conditions of success of the villages formed by the transformation of the Transmigration Settlement Unit (UPT) above will experience a paradoxical situation when compared to the Madapuhi Trans Village in Sula Islands Regency which was formed from the transformation of the Madapuhi Transmigration Settlement Unit, where communities were unable to improve their welfare after the village was formed that is. This is indicated by the real conditions of 
Madapuhi Trans Village, namely $100 \%$ of the roads are unstable and not paved, there are no households that use electricity from PLN and only 15 households use non-state electricity, distance to public facilities such as police stations, markets and health centers over 30 kilometers, drinking and cooking water is still taken from rivers and excavation wells, no cellular telephone signals and television broadcasts, distance to educational facilities (elementary, middle and high school) above 30 kilos meters, distance to practice sites doctor over 30 kilometers, distance to the capital city district 33.2 kilometers, and distance to the capital city of Sula Islands Regency above 100 kilometers (BPS Regency of Sula Islands, 2016). The various conditions above have not only shown public welfare but also in real terms have contributed to the underdevelopment of the Sula Islands Regency. This explanation also illustrates that there is something wrong in implementing policies related to the transformation of UPT into Madapuhi Trans Village. Departing from the various conditions above, this research is directed at implementing the policy of transforming transmigration settlement units into villages in improving the welfare of the community in the village of Madapuhi Trans Regency, Sula Island, North Maluku Province.

The research statement (problem statement) of this research is that the transmigration settlement unit policy into the village has not been able to improve the welfare of the village of Madapuhi Trans. Furthermore, the main question based on this formula is why the transmigration settlement policy into the village has not been able to improve the welfare of the people of the village Madapuhi Trans? This main question is then translated into the following questions:

1. How is the implementation of the policy of transforming transmigration settlement units into villages in improving the welfare of the community in Madapuhi Trans Village, Sula Islands Regency?

2. What factors hinder and support the implementation of the policy of transforming transmigration settlement units into villages in improving the welfare of the community in the Madapuhi Trans Village, Sula Islands Regency?

3. How is the model of the effectiveness of the process of transforming transmigration settlement units into villages?

\section{Theory}

In MacIver's view (1965: 248) that "government is for the sake of governing and not of the governors then all its activities are presumptively concerned with the public welfare". This shows that if the government concept is for governed interests (public interest) then all activities carried out by the government must lead to general welfare or in other words the function of the government is to carry out public welfare. Based on the explanation of the theory above, it can be seen that the presence of the government (an) with all the instruments of power that are attributively attached to it is to realize public welfare. These conclusions are also in line with the objectives of government revealed by Charles Merriam that the purpose of government includes external security, internal orders, justice, general life and freedom (Syafiie, 2011). From the explanation of this goal, it can be seen that the general welfare or 
society is one of the goals that must be achieved by the government, so that when these conditions cannot be created, it can be said that the government failed and did not fulfill its purpose as the bearer of people's power. Furthermore, to realize the welfare of the community, the government makes various policies that can accommodate various problems and solutions to the life of the state and society. Thus the policies made by the government in the form of programs are essentially instruments or instruments of the power entrusted by the constitution to the government to ensure that people can live more properly, both in terms of security, order, justice, and welfare. These programs will certainly be regulated specifically in accordance with the conditions and needs of the community, but in essence are related to development, empowerment and public services.

This is as the Government Model presented by Supriatna that the government in carrying out the government always adheres to the goals previously set, the system that has been built, the principles that are the handle of the organizers, the affairs that are the authority, the principle used as guidelines, techniques used as approaches and so on, where all of them are built on the interests and needs of the people/population (Supriatna, 2014). As a form of implementation of the concept, the government then issued various policies related to service, development and community empowerment. As for all the above processes, the aim is ultimate to create security, order, justice, and public welfare.

James E. Anderson quoted Suharto as saying that the policy is "a purposive course of action" (Suharto, 2010) or is a series of actions aimed at being followed by a person or group of actors regarding a problem or an interesting thing (an issue that develops and attracts the attention of the general public). Furthermore, Anderson noted five implications of the concept of public policy, namely: First, public policy is a goal-oriented action. Second, the public policy contains a series of actions taken all the time. Third, public policy is a response to the need for a policy regarding certain matters. Fourth, public policy is an illustration of the actual activities of the government and not just the wishes that are carried out. Fifth, government policy can be an active or passive activity in dealing with a problem (Hamdi, 2014).

All meanings of public policy are certainly very meaningful, but the most important thing is whether they can be implemented in accordance with the expectations of making these policies. Hamdi argues that the implementation or implementation of policies has to do with efforts to achieve the goals of establishing a certain policy (Hamdi, 2014). This stage basically relates to how the government works or the process carried out by the government to make policies produce the planned conditions. Thus the implementation of the policy is a stage that is passed as an effort for the decisions that have been taken so that more can ensure the success of a policy that has been made. In policy implementation, of course, it is very much influenced by various factors, both from internal and external decision making organizations. Hamdi said that the determinants of policy implementation are related to the substance of the policy, the behavior of implementing tasks, network interaction, the participation of target groups, and resources (Hamdi, 2014). More details as presented in the following table: 
Table 1. Determinants of Public Policy Implementation

\section{Factors}

(1)

Policy Substance

Executing Tasks Behavior

Interaction Networks Work

Target Group Participation

Resource
Indicators

(2)

1. Consistency in the derivation of policy content/specifications;

2. Alignment of policy content with other policy contents

1. Work Motivation

2. Abuse Authority Trends

3. Learning Ability

1. Cooperation between Executors

2. Relationships between levels of government

1. Level of acceptance of the benefits of activities

2. ability to contribute according to existing procedures

1. Funds Sufficiency

2. Availability of Executors

3. Equipment Sufficiency

4. Availability of Information

5. Speed of Technology

Source: (Hamdi, 2014)

Furthermore, it relates to the relationship between determinants or determinant dimensions as presented in the following figure:

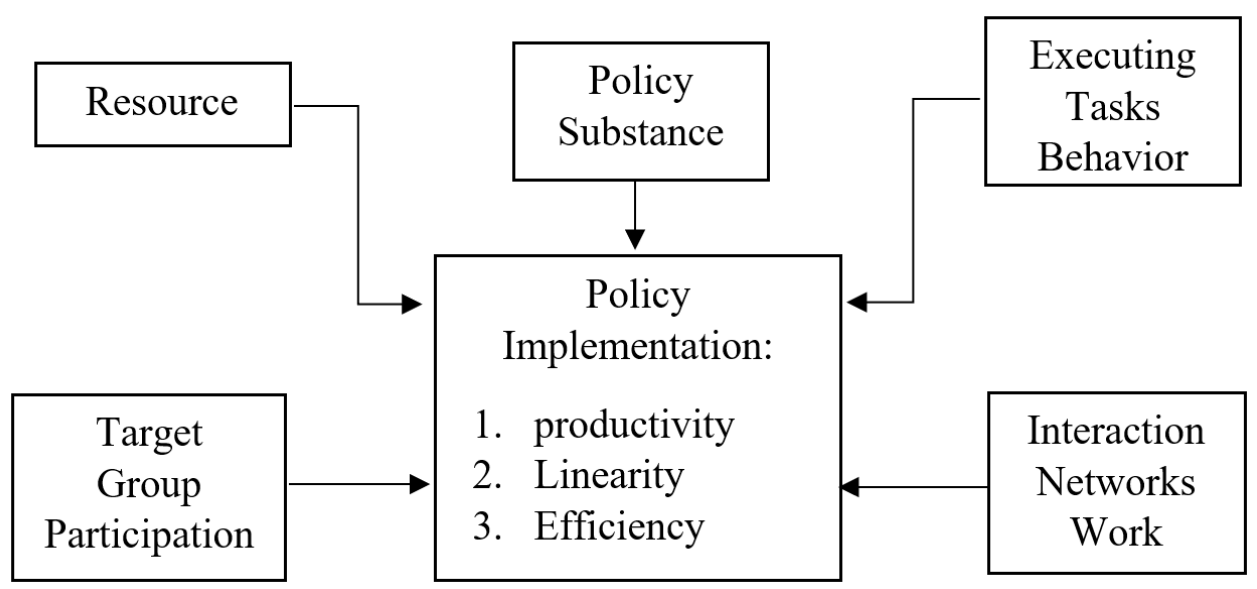

Figure 1. Dimensions and Determinants of Policy Implementation

Source: (Hamdi, 2014)

Based on the picture above, it can be seen that the policy implementation process consists of productivity factors related to the ability to realize performance in accordance with policy standards, linearity related to the conformity of the process of achieving performance 
standards with guidelines for implementing policies that have been prepared previously, and efficiency associated with utilization of resources in the implementation of policies, is strongly influenced by the participation of policy target groups, resources possessed by implementing policies, substances contained in policies, behavior of implementers policies, and interaction of networks that show the involvement of various stakeholders in policy implementation.

This research uses process theory and determinant of Hamdi's policy implementation as an analysis knife. The selection of this theory is based on consideration of the suitability of the research context with the dimensions and indicators discussed in the theory, where productivity, linearity and efficiency describe how the process of implementing transmigration settlement unit policies becomes a village in improving the welfare of the community in the village, as well as the substance of the policy, task behavior implementers, network interaction, participation of target groups and resources describing the supporting and inhibiting factors for the implementation of the policy of transforming transmigration settlement units into villages in improving the welfare of the community in Madapuhi Trans Village (Hamdi, 2014).

The formation of the village is an advanced stage of the existence of a group or community, which is present before as an agreement between individuals who wish to live together and are governed by the norms stipulated together. This understanding then gave birth to various concepts about the village, one of which was revealed by Marbun that the village was defined as a unitary area of law that existed since several offspring and generally had family ties or social ties to one another (Marbun, 1998). Similar thoughts were also conveyed by Effendy as the elaboration of Emile Durkheim's thinking about the existence of society as an initial element of village formation, that society is a collection of individuals who form a shared life system and have institutionalized structures and cultures (Effendy, 2009). Thus it is clear that the community as the forerunner of the formation of the village is a group of individuals who agree to build a system of shared life based on binding and structured norms in society, where the norms are taken from the cultural values and customs of the community, so the village formed has all the state's facilities so sometimes it is called a "small country" or by Ter Haar it is called a doorps republiek (Huda, 2015).

Etymologically, the village comes from the Sanskrit language, namely deca, which means homeland, native land or the land of birth. The village also means the place of origin, place of residence, country of origin, or ancestral land that refers to a single unit of life, with a unity of norms, and has clear boundaries (Swadesi) (Zid, 2016). Communities that have lived together will certainly lead to formal ties in conditions and boundaries of certain regions that separate them from other communities. This condition then prompted the community to form a village, as stated by Supriatna that communities living in the interior, outskirts, remote areas and other rural communities (gamainschap) formed villages on the basis of their initiatives, initiatives, creativity by paying attention to the origin and conditions local socio-cultural community (Supriatna, 2010). Furthermore, it was also explained that villages were formed on the basis of community unity based on their origins, customs, common interests, certain regions and the existence of village government organizations to regulate and manage the 
interests of their communities. Indeed, the nature of origin, customs, and socio-cultural conditions is something special in village formation, which then distinguishes it from the formation of other autonomous regions.

According to Nurcholis, villages are formed at the initiative of members of the local community, both on the basis of genealogical ties (sense of descent) and on territorial ties (regional feeling) and the mix between the two (Nurcholis, 2005). From the explanation, a red line can be made that the basis for the formation of a village is the genealogy of members of its community, territorial bonds and a mixture of the two. Communities or communal that are together for a long time will bring out blood ties among their fellowmen or indeed come from the same ancestors. Further developments will lead to the desire to form formal ties to protect the communal or the community from security, comfort and social aspects. Territorial or territorial ties are bonds that are formed from the conditions together with a community or community in a region because of certain conditions or conditions that cause them to gather and form communities with certain boundaries which they agree to form legal territorial agreements in the form of villages. Whereas mixed bonds are bonds that are formed not only because of blood relations among individuals in the community but also because they inhabit the same territory caused by certain conditions or situations for a long time. Territorial society has three forms, namely: 1) hamlet society (de Dorpgemeenshap), a society which is a set of people in one small area which usually includes settlement (shamanism); 2) the regional community (de Streeksemeenshap), is a development of several hamlets that form a larger legal community (parent hamlet); and 3) federated communities or a combination of hamlets (de Dorpenbond), consisting of a community of several adjoining hamlets (neighboring) to form an alliance to organize and manage interests together (Nurcholis, 2011). In line with this opinion, Surianingrat states that there are two forms of villages, namely: 1) Genealogical villages (generatie $=$ descendants), are villages where the population has family relations and comes from the same descendants, for example, Kanekes, Cibo and Cikeusik which is inhabited by Baduy people in South Banten, 2) Territorial Village (territoir $=$ area), this village has no ancestral relations with each other. The basis of territorial villages is that the population resides in the same area because the community has the same interests. The village that is generally present is now a territorial village (Surianingrat, 1985).

Furthermore, still with the same understanding, Nurcholis argues that from its origin, the village consists of four categories, namely:

1. Villages that are born, grow and develop based on kinship relationships so as to form genealogical legal alliances or descendants;

2. Villages that arise due to a close relationship so that they form a territorial legal alliance;

3. Villages that arise because of special objectives such as needs determined by ecological factors; and 


\section{Macrothink}

4. Villages that arise because of the existence of policies from above such as the decree of the king, colonial government ordinance, or the Law on Village Government such as transmigration villages in the present (Nurcholis, 2011).

In the formation of territory, there are several aspects that must be seen as the basis of consideration for the community to form a region (in the context of this research is village), namely: 1) geographical aspects is a form of feeling unity from community groups as a result of geographical ties. Geographical aspects assume that the geographical conditions of an area will influence the formation of the identity of a community group which will eventually develop into a social entity, 2) socio-cultural aspects, a form of identity that is closely related to entity and religious groups or communities, 3) demographic aspects, is the existence of society, where the homogeneity of the population can form a strong community unity bond and will encourage the formation of territory, and 4) the historical aspect, which assumes the historical structure of past governance of a community will influence the desires of the community to form a region (Ramses, 2006). Whereas according to Roucek and Warren, Supriatna quoted, the characteristics of the village are 1) the size of the primary group, 2) the geographical factor which is crucial for the formation of groups or associations, 3) social relations on the basis of intense and long social psychology, 4) village communities homogeneity, 5) low mobility, 6) the family emphasizes its function as an economic unit, and 7) the population of children in a large proportion (Supriatna, 2010).

From any aspect the village is seen and understood as a genealogical entity within the framework of regional expansion, but one thing that needs to be used as a backing and benchmark when establishing a policy for the establishment and or division of village areas, namely the function of the village itself, because from that direction and/or amalgamation. Bintarto states that village functions are as a unit of life, socio-cultural units, economic units and political units (Bintarto, 1984). Further explanation of this function is presented in the form of Scheme 1B below:

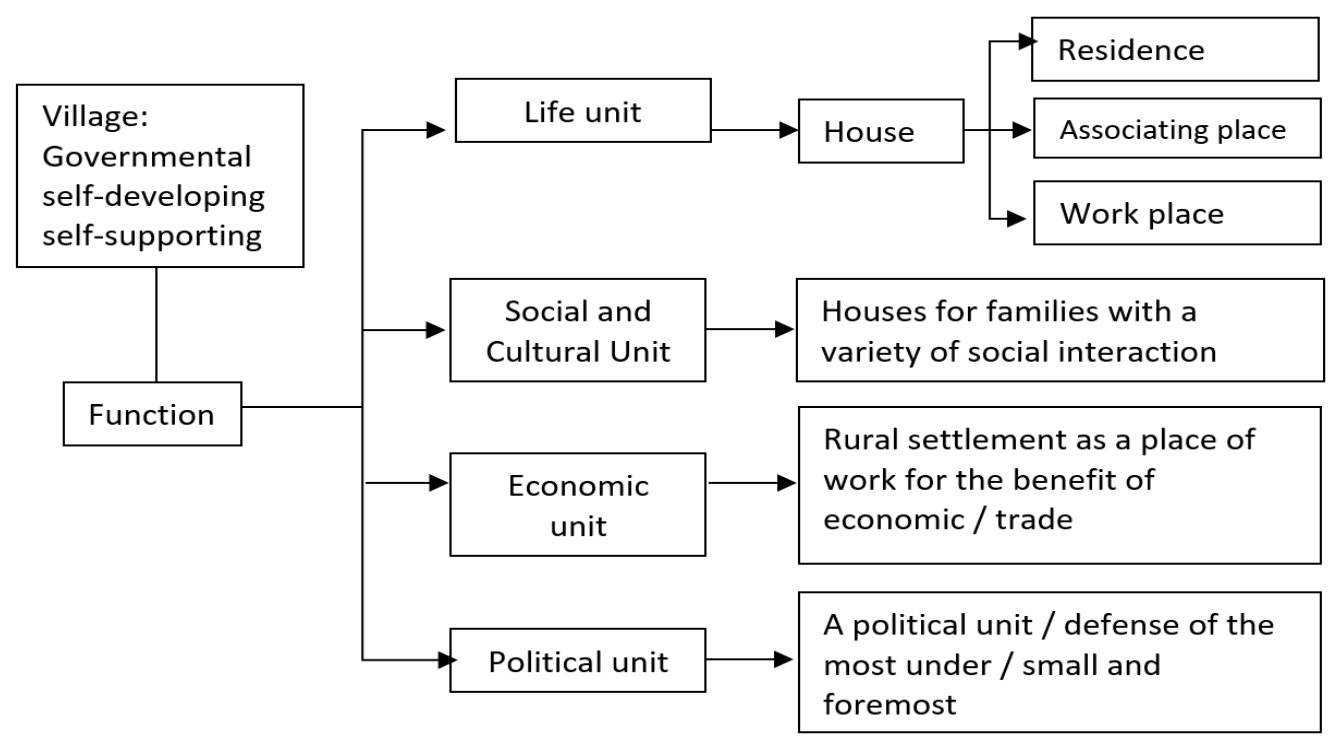

Figure 2. Developing of Rural Development 
Source: (Bintaro, 1984)

From the above scheme, it can be seen that villages (both self-supporting, self-supporting and self-sufficient villages) function as living units, socio-cultural units, economic units, and political units. As a unit of life, the village is a home that functions as a place to live, a place to hang out and a place to work. As a socio-cultural unit, the village functions as a home for families with various forms of social interaction in it. The village as an economic unit implies that the village is a settlement that functions as a place of work for economic or commercial interests. As a political unit, the village is the lowest or the smallest and most important political or defense entity within the framework of a unitary state.

One of the arrangements regarding village structuring is village formation, a concept contained in the substance of Law Number 6 of 2014. In Article 8 of Act Number 6 of 2014, it is explained that a village formation is an act of holding new villages outside the village through regional regulations. Considering the initiative of the village community, origin, customs, socio-cultural conditions of the village community, as well as the ability and potential of the village. Further explanation regarding village formation is regulated in Government Regulation Number 43 of 2014, which is the implementing regulation of Law Number 6 of 2014, wherein article (6) it is explained that village formation carried out by the district/city local government is based on the evaluation results the level of village development in the region, taking into account the initiative of the village community, origins, customs, socio-cultural conditions of the village community, and the ability and potential of the village. As for the purpose of the establishment of the village, it is very clearly stated in Article 2 of Law Number 28 of 2006, that the establishment of villages aims to improve public services in order to accelerate the realization of public welfare.The formation of villages in transmigration settlements which are in positive law was initiated by the government, regulated in 2 (two) laws, namely Law Number 6 the Year 2014 concerning Villages and Law Number 29the Year 2009 concerning Amendments to Law Number 15 the Year 1997 concerning Transmigration. In Article (13) of Law Number 6 of 2014, it is stated that the Government can initiate the formation of villages in the region that are specific and strategic for national interests. The interpretation of this specific area is then elaborated in the explanation of the PP, namely, what is meant by "areas that are specific and strategic in nature" such as the outermost areas within the border regions between countries, transmigration programs, and other programs considered strategic.

Based on Law Number 29 of 2009 concerning Amendments to Law Number 15 of 1997 concerning Transmigration, especially Article 32 paragraph (5) it is explained that in terms of community development in the Transmigration Settlement it has reached the set target or at the latest 5 (five) years since placement, the development of transmigration settlements has become the full responsibility of the district/city government. Understanding of article 32 paragraph (5) as in the explanation, describes that no more than 5 (five) years since the placement of the last transmigration in transmigration settlements, the target of transmigration community development must be achieved. Therefore, community development in transmigration settlements becomes a unit with government services and the implementation of relevant regional development and is fully the responsibility of the 
district/city government.

Based on the above explanation, it is clear that village formation is strongly related to improving the welfare of rural communities, as also expressed by Jamaludin that the purpose of the establishment of the village is to improve the ability to administer the government efficiently and successfully and improve services to the community in accordance with the level of development and development progress (Jamaludin, 2015). From the above opinion, it is illustrated that with the formation of the village will improve the ability to administer the government and service to the community, where if the administration of government and especially services to the community can run well then automatically there will be an increase in the welfare of the people served.

\section{Method}

As a natural research that is the basis of qualitative studies, this study will review the implementation of village formation policies in transmigration areas in improving the welfare of the community by taking the location of Madapuhi Trans Village in Sula Islands Regency. This research is basically an effort to find the truth or strengthening the existing truth, this study tries to explore and reveal various symptoms or phenomena experienced and felt by the people of Madapuhi Trans Village related to the policy of forming or transforming the Transmigration Settlement Unit into a village.

In an effort to facilitate research and so as not to cause bias in designing research, this research always relies on some basic characteristics of qualitative research. First, the construction that is built is based on natural conditions, where data is obtained directly from the source and the researcher himself is the main instrument. Second, it is more descriptive, where the data collected and collected is more in the form of photographs or records (manuscripts) and does not emphasize mere numbers. Third, more emphasis on the process than the final result. The four dominant data analyzes were conducted inductively. Fifth, more emphasis on the value or meaning contained in a data or event, not just the magnitude and determinant of data or events in the arrangement of research variables.

To obtain accurate data and meet the desired standards, researchers used 4 (four) data collection techniques, namely: 1) Observation, 2) Interviews, 3) Documentation and 4) Triangulation or a combination. In the process of collecting data with in-depth observation and interviews, researchers will meet and interview directly and in-depth with key informants who are directly involved and, in a position, to know and understand what is related to the domain of transmigration settlement policy implementation became the Trans Madapuhi village of Sula Islands Regency and whether the implementation of the policy went well and could improve community welfare. In addition, in-depth observations were also conducted by researchers at the research location, where the author will stay in a certain period of time and observe carefully and deeply on all phenomena and factual conditions that did occur and apply in Madapuhi Trans Village, such as how the economy and village infrastructure are how is the life of the village community every day, how are the socio-cultural conditions of the community, how is the role of the government in educating and facilitating the village community. In observations, researchers will always record each field finding without 
missing any related information, records are made after observation and directly analyze it, compile a schedule of observations, and always maintain reliability consistently in the same decision about an event or event in observation. Primary and secondary data such as documents, interview data and the results of observations in this study were analyzed using the Flow Model from Miles and Huberman.

\section{Discussion}

\section{The Process of Implementing the UPT Transformation Policy into a Village}

According to Hamdi the indicators of policy implementation (policy process) consist of a series of images (subject or circumstance) regarding the dynamics of policy implementation movements. This study will see the process of implementing the transformation policy UPT into a village with 3 (three) dimensions, namely the dimensions of productivity, dimensions of linearity and dimensions of efficiency (Hamdi, 2014).

Productivity is related to the ability to realize the achievement of predetermined standards, especially regarding the achievement of the standard number of target groups. Hamdi further explained that the more smoothly fulfilling the target group's achievements, it could be said that the implementation of the policy was more productive. Regarding the context of the implementation of the transmigration settlement unit transformation policy into the Madapuhi Trans Village, the intended target group is the Madapuhi Trans Village community. Whereas the purpose of implementing the transmigration settlement unit transformation policy into Madapuhi Trans Village is to realize the welfare of the people in Madapuhi Trans Village, so that in substance, the goal to be achieved in implementing this policy is a prosperous society in accordance with the implementation of the policy of transforming transmigration settlements into Madapuhi Trans Village.

The welfare condition in Madapuhi Trans Village is seen based on welfare level indicators from the Central Statistics Agency which consists of 8 (eight) indicators, namely: income, consumption or family expenses, conditions of residence, housing facilities, health of family members, ease of getting health services, ease of entering children into the level of education, and the ease of obtaining transportation facilities. The following are presented data on the conditions of the Madapuhi Trans Village community related to the eight welfare indicators from the Central Statistics Agency.

Based on the facts in the field, it can be seen that the people of Madapuhi Trans Village are still classified as a society that is not yet prosperous, this is characterized by relatively low-income levels, low expenditure, average non-permanent and uninhabitable dwellings, housing facilities are still lacking, the health of family members is only enough, it is still difficult to obtain health services, it is still difficult to include children in education, and transportation that is still difficult to access.

The facts and descriptions above show that the goals to be achieved from the transformation of transmigration settlement units into Madapuhi Trans Village are as mandated by Law Number 6 Year 2014 concerning Villages and Regional Regulation Number 7 of 2008 concerning the Establishment of New Villages in the Sanana North District Area, South 
Sulawesi, North Mangoli, Taliabu Selatan Timur, Taliabu Barat and Lede Regency Sula islands have not been reached and tend to run smoothly, which is indicated by the unrealized goal of transforming transmigration settlements into Madapuhi Trans Village, especially concerning improving community welfare and improving the quality of implementation and village government services. based on these matters, the implementation of the policy of transforming transmigration settlement units into Madapuhi Trans Village has not been productive.

Besides productivity, linearity is also a dimension seen in the process of implementing the UPT transformation policy into Madapuhi Trans Village. According to Hamdi, linearity is related to the conformity of the process of fulfilling the standard with the specified standard specification guidelines. Compliance is related to procedures, time, costs, place and implementation. The more appropriate the process of fulfilling the standards in policy implementation, it can be stated that the implementation of the policy is increasingly linear (Hamdi, 2014). Hamdi further notes the term suitability as something that does not exceed the prescribed standards, namely procedures that are not longer, time is not longer, costs are not getting bigger, places are not changing, and implementers are not getting bigger the amount.

Research in the field shows that in the formulation and implementation of the policy of establishing the Madapuhi Trans Village, the regional government does not have an operational standard (SOP) so that it only refers to the authority it has so that the policies taken are centralized without two-way communication with the community. Likewise, the time required for implementing this policy is too short, so that the important steps in the implementation process are neglected. The implementation process tends to be simplified following the timelines desired by the regional head without considering the participation of various stakeholders, so that the transformation of the UPT into Madapuhi Trans Village looks so fast, but ultimately results in a failed village to realize the welfare of its people.

Regarding costs, places, and implementers, findings in the field indicate that the costs used are still lacking when compared to the number of activities and procedures that must be carried out. Likewise with implementers who are still very lacking when compared to the workload that has been displaced into the stages and Auth of the relevant Work Units. Whereas the place is an indicator that is considered linear because it does not change during the planning process until the implementation of the UPT becomes the Village of Madapuhi Trans. However, the location feasibility factor is not considered, where from the beginning a feasibility study was not carried out so that the location of the UPT Madapuhi Trans which from the aspect of accessibility, natural potential, economic potential, and geographical conditions were not feasible but still forced into a village. this then caused the welfare of the community not to increase, because it was not supported by natural resources, geographical conditions, and adequate accessibility.

Understanding efficiency essentially concerns the effective output ratio of the input needed to achieve it. For example, a hospital is said to be efficient if it successfully meets the needs of customers with lower costs (Wibowo, 2012). Whereas in this study, the efficiency referred to is related to policy. The efficiency of the policy according to Hamdi is related to the ability to 
utilize resources in policy implementation (Hamdi, 2014).

The results of the study illustrate that when viewed from the many resources used, the process of implementing the UPT transformation into a village policy seems efficient, but if it is seen from the effective output ratio to inputs, the UPT implementation process into Madapuhi Trans Village is still not efficient. This is due to the minimal use of resources, the process of implementing the transformation of UPT into Madapuhi Trans Village has not been able to improve community welfare.

\section{The determinant of Policy Implementation in Transforming Technical Implementation Units into Villages}

Hamdi argues that the factors that influence the implementation of policies include the substance of policy, the behavior of implementing tasks, network interaction, participation of target groups, and resources (Hamdi, 2014). According to Hamdi, the substance of the policy is pleasing to the consistency of derivation of the content or specification of policies and alignment of the contents of the policy with the contents of the other policies (Hamdi, 2014). In the context of the implementation of the transformation of the Transmigration Settlement Unit into Madapuhi Trans Village in North Mangoli Subdistrict, Sula Islands Regency, the substance of the policy referred to by Hamdi referred to the Sula Islands Regency Regulation Number 7 of 2008 concerning the Establishment of New Villages in the Sanana Utara District, South Sulawesi, North Mangoli, South East Taliabu, Taliabu Barat and Lede Sula Islands Regency.

The results of the study found that the policy substance in the Sula Islands Regional Regulation Number 7 of 2008 concerning the Formation of New Villages in the Sanana North District, South Sulawesi, North Mangoli, Taliabu Timur Selatan, Taliabu Barat and Lede Regency of the Sula Islands, had not been specifically regulated about the formation of the village from the transformation of the UPT, but is still general in nature, which is intended for the formation of a geological village. Whereas from the aspect of compliance with other regulations, Perda Number 7 of 2008 concerning the Establishment of New Villages in the North Sanana Subdistrict, South Sulawesi, North Mangoli, Taliabu Timur Selatan, Taliabu Barat and Lede Regency Sula islands are not yet appropriate, but do not conflict with regulations above, so it can be concluded that the contents of Regional Regulation Number 7 the Year 2008 have not been in harmony with other laws and regulations that have caused the substance of the policy to be an inhibiting factor.

Implementing task behavior is one of the dimensions seen also in this study. Hamdi revealed that the behavior of implementing tasks includes things such as work motivation, the inclination to abuse or abuse of authority, and learning abilities (Hamdi, 2014). Facts and results of research in the field show that low work motivation, tend to do deviation or abuse of authority and low learning abilities. This shows that in general the behavior of the executing task becomes an obstacle in the implementation of the transformation of the UPT into the Madapuhi Trans Village.

Network interaction is a dimension that is also analyzed in this study, which according to 
Hamdi is related to cooperation between implementers and relations of authority between levels of government (Hamdi, 2014). The theory conveyed by Hamdi in the context of this research is the collaboration between implementers of the transformation policy of the transmigration settlement unit into the village of Madapuhi Trans in Sula Islands Regency and the relationship of authority between levels of government, both hierarchical government relations in the Sula Islands government organization and in a broader context, namely the authority relationship between the Central Government, the Government of North Maluku Province and the Sula Islands Regency Government. This is because every regional government policy in the form of regional regulations, especially at the district/city level, will be hierarchically consulted with the province and the central government as a consequence of the division of authority within the frame of the unitary state of the Republic of Indonesia.

This research shows that the collaboration between implementers has only been carried out not involving all parties involved in the implementation of the UPT transformation policy into Madapuhi Trans village, but the hierarchical authority has gone quite well, where all levels of government understand and place themselves in accordance with their authority. In general, it can be concluded that the interaction of the network is good enough, so it is included as a supporting factor in the implementation of the UPT transformation policy into the village of Madapuhi Trans.

In addition to the bureaucratic aspect, the aspect of society is also an important part analyzed in the implementation of the transformation of the UPT into Madapuhi Trans Village. The Society aspect being analyzed is the participation of the target group, which according to Hamdi is indicated by the level of acceptance of the benefits of activities and the ability to contribute in accordance with existing procedures (Hamdi, 2014). The level of acceptance of the benefits of activities refers to how much the quantity and or quality that can be felt by the target group, especially regarding the level of welfare. The ability to contribute in accordance with existing procedures is an indication of the participation of target groups through various means that enable them to participate.

The level of acceptance of the benefits of the policy of transforming transmigration settlement units into villages for the people of Madapuhi Trans Village, based on facts and field findings shows that they are still very low, especially regarding their level of welfare. The community, in general, believes that the policy of changing transmigration settlement units to villages has not yet had a good impact on increasing their income or welfare. Likewise, the ability to contribute to the community in the implementation of the transformation of the UPT into Madapuhi Trans Village and their contribution in the implementation of development after the establishment of the Madapuhi Trans Village is still very low. This condition is caused more by a lack of socialization and interaction between the implementor and the target group. Implementor tends to work bureaucratically and dwell on administrative matters and thinks that the realm of village formation is the realm of government, the community must follow the wishes of the government to know what is needed by the community. While on the other hand, the community feels set aside in the process of implementing the transformation of UPT into a village, even though they assume that they know better what they need and better understand the conditions of the UPT to be 
transformed into the Madapuhi Trans Village. This condition has resulted in the community becoming apathetic in the implementation process and not supporting all programs held by the regional government, which in turn will give birth to a pessimistic attitude to survive in the village of Madapuhi Trans. This then caused almost the majority of the early inhabitants of Madapuhi Trans Village, which were transmigrants, to leave the village. Based on this condition, the participation of the target group is a factor that hinders the implementation of the transformation of the UPT into the Village of Madapuhi Trans.

The next dimensions analyzed are related to resources, which Hamdi revealed as the availability of resources consisting of sufficient funds, availability of implementers, adequacy of equipment, availability of information, and accuracy of technology (Hamdi, 2014). The theory in the context of this study is the adequacy of funds in the implementation of the policy of transmigration residential unit transformation into villages, whether it has enough policy implementers (implementor), has enough equipment needed when implementing policies, whether the information needed is sufficient and the technology used in the implementation process the policy. The conditions at the time of the implementation of the transformation of UPT into Madapuhi Trans Village showed that the implementers involved in implementation were very limited, the available funds were very lacking and the equipment conditions were lacking and limited, information related to various data needed in implementation was also limited and limited, and technological specifications which are used are not in accordance with the technical standards needed in the digital era. These various limitations then caused the dimension of resources to be included as a limiting factor in the implementation of the UPT transformation policy into Madapuhi Trans Village.

In addition to the five dimensions above, the research findings show that there is one more dimension that is quite influential in the implementation of the UPT transformation policy into Madapuhi Trans Village, namely the dimension of understanding harmony. The problems that arise in the implementation of the UPT transformation policy into Madapuhi Trans Village, especially concerning the participation of target groups as the main inhibiting factor, are actually not stand alone or in other words because the community feels marginalized and the local government does not involve them in the implementation process, but rather due to the lack of harmony between the two parties. The community wants to be involved in the implementation process assuming more understanding of their needs and the government feels most know what the community needs, it should be solved by equating perceptions related to the issues raised so that understanding alignment can be made regarding the issue of UPT transformation into Madapuhi Trans Village. Field findings indicate that there is no harmony of understanding between implementers and target groups caused by no party facilitating the meeting between the two so that their position of perception of the best is still attached to their respective groups. This condition then gave birth to the participation of low target groups and implementers' behavior who tended to abuse their authority. The dimensions of understanding alignment based on facts and field findings are grouped into factors that hinder the implementation of the UPT transformation policy into Madapuhi Trans Village. 


\section{Mll Macrothink \\ Journal of Public Administration and Governance \\ ISSN 2161-7104 \\ 2019, Vol. 9, No. 2}

\section{Effective Process Model of UPT Transformation into a Village}

The existing model of policy implementation used in the implementation of the transmigration settlement unit policy into Madapuhi Trans Village is the Top-Down Model or from the top down, where the approach of this model assumes that the things that have been decided (policy) are the best alternatives, and in order to achieve the best results then administrative control in its implementation is an absolute thing (Anggara, 2014). This model has proven to have failed to be implemented in the case of the transformation of the UPT into Madapuhi Trans Village. Based on the failure of existing models and various findings and results of the analysis, then a more effective model was made in the implementation of the UPT transformation policy into the Madapuhi Trans Village as follows:

The model of the effectiveness of the UPT transformation process into a village illustrates that there is a realm of government administration which is the attributive authority of the government and regional government, takes place in a top-down manner, but is related to the target group (village community). This is expected to result in a harmonious understanding between the two parties which will have an impact on the synergy between the two in responding to the implementation of the transformation of the UPT into the Madapuhi Trans Village. This model also produces several rational choices related to the feasibility of village formation, where preparatory villages that are not feasible or do not meet the requirements after evaluation can be combined with the nearest village which has a better level of progress compared to other surrounding villages. As for eliminating the perceptions and conditions burdened by villages that receive preparatory villages that are not feasible to become villages, financial incentives are provided in the form of additional village budgets or other budgets that are in accordance with laws and regulations. This model is expected to be more effective than the existing model in improving people's welfare. 


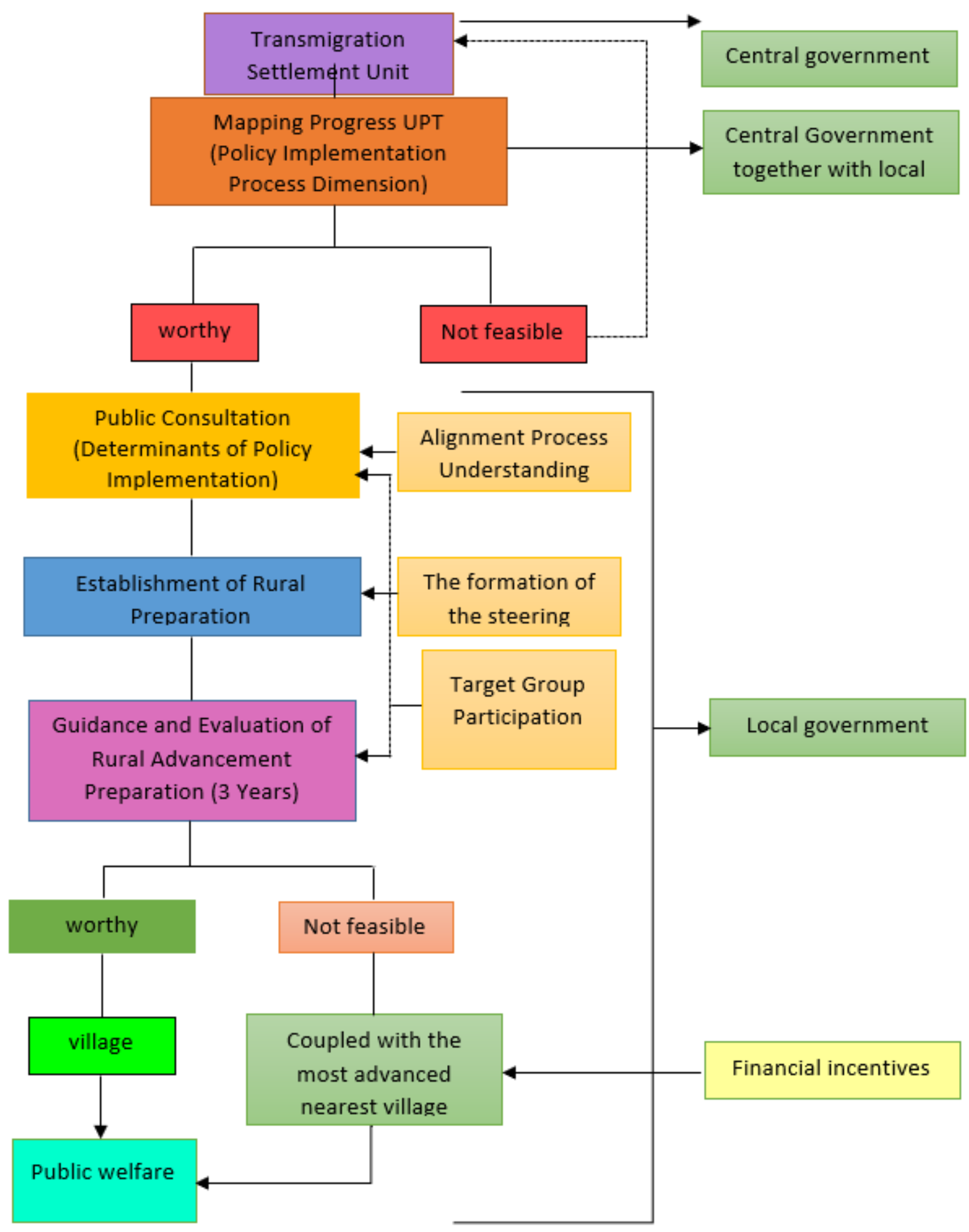

Figure 3. Effective Process Model of UPT Transformation into a Village

Source: managed by author 


\section{Closing}

Referring to the conclusions of the results of this study, namely Low Productivity in the implementation of the transformation of transmigration settlement units into villages as illustrated by the achievement of the prosperous target groups that are very low in linearity in the implementation of transmigration residential unit transformation into villages indicated by many non-implemented procedures, low in the implementation of the transmigration settlement unit transformation, it can be seen from the many resources in the form of implementers, assets, funds and technology and the existence of several inhibiting factors in implementation such as the absence of consistency in policy content or specifications, low work motivation, abuse of authority and learning abilities which is still low, the level of acceptance of benefits is still low and the ability to contribute according to existing procedures is also still low, the available funds are still very limited, ksana available is still lacking when compared to the existing workload and the available information is still lacking, and the understanding of the target group regarding the benefits and objectives of transforming UPT into a Village is still very lacking, so the recommendations submitted are so that the effectiveness process model produced in this study can be developed and implemented in the process of transforming UPT into a village in various regions in Indonesia, it was also used as a basis for improving the Village Law, especially in relation to articles on village formation originating from UPT and village transformations formed in border areas.

\section{Reference}

Bintarto, R. (1984). Interaksi Desa Kota dan Permasalahannya: cetakan kedua. Jakarta: Ghalia Indonesia.

Effendy, K. (2009). Otonomi Desa: Historis dan Kontekstual. Bandung: CV. Indra Prahasta.

Effendy, K. (2014). Kebijakan Publik: Proses, Analisis, dan Partisipasi. Bogor: Ghalia Indonesia.

Huda, N. (2015). Hukum Pemerintahan Desa. Malang: Setara Press.

Jamaludin, A. N. (2015). Sosiologi Perdesaan. Bandung: Pustaka Setia.

MacIver, R. M. (1965). The Web of Government. New York: The MacMillian Company.

Marbun, B. N. (1998). Proses Pembangunan Desa Menyongsong Tahun 2000. Jakarta: Erlangga.

Nurcholis, H. (2011). Pertumbuhan dan Penyelenggaraan Pemerintahan Desa. Jakarta: Erlangga.

Suharto, G. D. (2016). Membangun Kemandirian Desa: Perbandingan UU No. 5/1979, UU No. 22/1999, \& UU No. 32/2004 serta Perspektif UU No. 6/2014. Yogyakarta : Pustaka Pelajar.

Supriatna, T. (2010). Sistem Pemerintahan Desa. Bandung : Indra Prahasta. 
Supriatna, T. (2014). Birokrasi dan Pemerintahan Daerah. Jakarta : Nagamedia.

Surianingrat, B. (1985). Pemerintahan Administrasi Desa dan Kelurahan. Jakarta: Aksara Baru.

\section{Copyright Disclaimer}

Copyright for this article is retained by the author(s), with first publication rights granted to the journal.

This is an open-access article distributed under the terms and conditions of the Creative Commons Attribution license (http://creativecommons.org/licenses/by/4.0/). 